\title{
THE APPLICATION OF TAXONOMIC METHODS AND ORDERED LOGIT MODEL IN THE ASSESSMENT OF FINANCIAL SELF-SUFFICIENCY OF LOCAL ADMINISTRATIVE UNITS
}

\author{
Aleksandra kuczak ${ }^{1}$, Ph.D; Agnieszka Kozera², Ph.D. and Silvia Bacci ${ }^{3}$, Ph.D. \\ ${ }_{1,2}$ Poznań University of Life Sciences; ${ }^{3}$ Universita degli Studi di Perugia
}

\begin{abstract}
The purpose of this paper was to identify the internal determinants of financial self-sufficiency of local government units, as illustrated by the example of Polish municipalities of the Wielkopolskie voivodeship, with the use of taxonomic methods and the ordered logit regression model. The first step of the proposed approach is to assess financial self-sufficiency of the municipalities using taxonomic methods, in order to subsequently model it with econometric techniques. In the first phase, the local government units' (LGU) financial self-sufficiency was assessed with positional TOPSIS (Technique for Order Preference by Similarity to an Ideal Solution). The results of this phase, that is, municipalities were grouped into classes by financial selfsufficiency level, were assumed to be the baseline. Afterwards, the ordered logit regression model was used. The estimated model allowed us to specify the significance (strength and direction) of selected socio-economic development factors for the financial self-sufficency level of administrative units under consideration. The empirical basis for this study was statistical data for 2013 delivered by the Local Data Bank of the Central Statistical Office in Poland. The study confirmed that the size of local economic operators and the number of hotel beds stimulated the improvement of financial self-sufficiency levels of municipalities in the Wielkopolskie voivodeship, while the unemployment rate and the share of rural population in the total population were restraining factors.
\end{abstract}

Key words: taxonomy method, TOPSIS, ordered logit model, financial self-sufficiency, local administrative units

JEL code: $\mathrm{C} 01, \mathrm{C} 02, \mathrm{R} 110$

\section{Introduction}

Autonomy is usually interpreted as the right of a specific community to settle their internal affairs by themselves; this includes freedom and independence in making individual decisions (Pratchett, 2004). The autonomy (self-sufficiency) of the local government needs to be mainly considered in the financial context. This is because the financial self-sufficiency of local government units, which plays a major role for assessing their financial condition, is a key driver of a stable local development. According to Surowka (2013), the autonomy of LGUs is related, from the financial perspective, to the ability of the municipal authorities to freely decide of their incomes and revenues, and of amounts and targets of expenses and uses; and also implies independence in planning and executing the municipal budget. Financial self-sufficiency is a condition for the existence of self-government authorities. Note also that sustainable financial resources are the basis for the local socio-economic development, especially as regards rural areas. It is also the basic category that is taken into account in the analysis of financial stability of LGUs.

Financial self-sufficiency of local government units is conditioned by multiple factors, including spatial determinants (location, ease of transport), urbanization level, and the demographic and economic potential (Standar, Kozera, 2017). The analysis of internal determinants of the financial situation of local government units, with particular focus on their financial self-sufficiency levels, is an important research topic from the economic and social perspective

The main purpose of this paper is to identify the internal determinants of financial selfsufficiency of local government units, as illustrated by the example of Polish municipalities of the Wielkopolskie voivodeship, with the use of taxonomic methods and the ordered logistic regression. Data used in this study have were obtained from the Local Data Bank of the Central Statistical Office in Poland (year 2013). 


\section{Research methodology}

The following research approach, comprising the two main phases listed below, was proposed for the procedure of multidimensional assessment of financial self-sufficiency levels of Polish municipalities in the Wielkopolskie voivodeship (Luczak and Wysocki, 2013).

Phase 1. The procedure to construct a synthetic measure based on TOPSIS (Technique for Order Preference by Similarity to an Ideal Solution) (Hwang, Yoon, 1981) method is a multi-step process, which includes: (i) selecting features of the complex phenomenon (i.e., the financial self-sufficiency of the LGU), (ii) determining the nature of features in relation to the main criterion under examination, (iii) normalizing the values of features, (iv) calculating the distance of each unit (municipality) from positive and negative ideal solutions, ( $v)$ calculating values of the synthetic development index (the synthetic measure), and (vi) linearly ordering and identifying the types of financial self-sufficiency of municipalities considered.

Phase 2. Identification of socio-economic statistically significant determinants of the financial self-sufficiency of municipalities of the Wielkopolskie voivodeship through an ordered logit regression model. We focused on the identification of explanatory variables, estimation of regression coefficients of the logit model, and interpretation of the main results.

In the first phase of this study, the positional TOPSIS method was used to synthetically assess the financial self-sufficiency levels of municipalities covered. This is because the financial selfsufficiency of LGUs is a multidimensional phenomenon that cannot be directly measured. Attempts can only be made to describe it with many features (indicators), which can then be used as a basis for assessment with a synthetic measure. The method employed, TOPSIS, is based on the Hellwig's (1972) idea of constructing a synthetic feature. It enables a synthetic assessment of a phenomenon with multiple features (see Hwang, Yoon 1981). To describe the financial selfsufficiency of selected units, in this study was used features selected based on a substantive and statistical analysis. Afterwards, features need to be grouped by determining the direction of their impact on the general criterion under consideration, that is, the level of financial self-sufficiency. The selected features may have a stimulating or destimulatingeffect on the phenomenon. Features that have stimulating effect, contribute to increasing the level of the phenomenon, while feature that have destimulating effect, decreasing the level of the phenomenon. Features considered to have a destimulating effect may be converted into stimulating features with the use of a negative coefficient transformation. The set of features describing the financial condition usually includes strongly asymmetric items or outliers. Therefore, this study uses the Weber's median standardization which is tolerant to such values. It is based on the following formula (Lira, Wagner, Wysocki 2002):

$$
z_{i k}=\frac{x_{i k}-m \tilde{e} d_{k}}{1.4826 \cdot m \tilde{a} d_{k}}
$$

with: $x_{i k}$ value of the $k$ th feature $\left(k=1,2, \ldots, k_{1}\right)$ in the $i$ th object (municipality) $(i=1,2, \ldots$, $N), \quad m \tilde{e} d_{k} L_{1}$-median (Weber median) vector component corresponding to the $k$ th feature, $m \tilde{a} d_{k}=m e d_{i}\left|x_{i k}-m \tilde{e} d_{k}\right|$ median absolute deviation of $k$ th feature values from the median component of the $k$ th feature, 1.4826 constant scaling factor corresponding to normally distributed data $\left(\sigma \approx E\left(1.4826 \cdot m \tilde{a} d_{k}\left(X_{1}, X_{2}, \ldots, X_{K}\right)\right)\right.$ and $\sigma$ standard deviation) (Mlodak, 2006). 
Then, the coordinates of positive ideal solution (PIS) and negative ideal solution (NIS) were computed according to the following formulae:

$$
\begin{aligned}
& A^{+}=\left(\max _{i}\left(z_{i 1}\right), \max _{i}\left(z_{i 2}\right), \ldots, \max _{i}\left(z_{i K}\right)\right)=\left(z_{1}^{+}, z_{2}^{+}, \ldots, z_{K}^{+}\right) \\
& A^{-}=\left(\min _{i}\left(z_{i 1}\right), \min _{i}\left(z_{i 2}\right), \ldots, \min _{i}\left(z_{i K}\right)\right)=\left(z_{1}^{-}, z_{2}^{-}, \ldots, z_{K}^{-}\right) .
\end{aligned}
$$

Coordinates of PIS and NIS constitute the basis for the calculation of distances for each assessed object from the positive ideal solution $\left(A^{+}\right)$and the negative ideal solution of development $\left(A^{-}\right)$to the following formulas:

$$
d_{i}^{+}=\operatorname{med}_{k}\left(z_{i k}-z_{k}^{+} \mid\right) \quad d_{i}^{-}=\operatorname{med}_{k}\left(\left|z_{i k}-z_{k}^{-}\right|\right)
$$

where $d_{i}^{+}$and $d_{i}^{-}$denote the median absolute deviation from the positive ideal solution $\left(A^{+}\right)$ and negative ideal solution $\left(A^{-}\right)$for the ith object, respectively, and $\operatorname{med}_{k}(\cdot)$ is the marginal median for the $k$ th feature.

To construct the synthetic measure, the TOPSIS method was used using the formula (stage 5) (Hwang, Yoon, 1981; Wysocki, 2010):

$$
S_{i}=\frac{d_{i}^{-}}{d_{i}^{-}+d_{i}^{+}}
$$$$
,(i=1,2, \ldots, N) \text {, }
$$

The values of the synthetic feature $S_{i}$ are within the interval $[0,1]$. The closer a unit to the development pattern (and the further it moves away from the anti-pattern), the closer to 1 is the value of the synthetic indicator. The determined values of the synthetic measure are linearly ordered and become the basis for grouping the municipalities into typological classes by financial self-sufficiency level. The entire range of the synthetic measure was arbitrarily divided into classes. This study assumes the values of indicator $S_{i}$ to fall within the following numerical intervals: $[0.00,0.20)$ - very low level, $[0.20,0.40)$ - low level, $[0.40,0.60)$ - medium level, $[0.60,0.80)$ high level, $[0.80,1.00]$ - very high level.

The classes of Wielkopolskie voivodeship municipalities, established in function of financial selfsufficiency levels, became the basis for formulating an ordered logit regression model for cumulative probabilities (Hilbe, 2009; Cramer, 2011). This type of model allows us to properly account for the ordinal nature of response variable of our interest (i.e., classes of identified types of financial self-sufficiency levels of municipalities, combined with a system of socio-economic indicators) and its estimation provides a more in-depth insight into the reasons for differences in the municipalities' financial self-sufficiency levels.

To identify the determinants of the financial self-sufficiency level of municipalities under consideration, the following ordered logit model (proportional odds model) was used (Borooah, 2001; Cameron, Trivedi, 2005; Hilbe, 2009):

$$
y_{i}^{*}=x_{i}^{T} \beta+\varepsilon_{i}
$$

with:

$$
x_{i}^{T} \beta=\beta_{0}+\beta_{1} x_{1 i}+\beta_{2} x_{2 i}+\ldots+\beta_{K_{2}} x_{K_{2} i} ;
$$


$y_{i}^{*}$ latent variable for $i$ th municipality; its discrete equivalents $y_{i}$ correspond to the identified classes of financial self-sufficiency level, determined as above described;

$x_{i}$ vector of explanatory variable values for ith municipality (determinants of the municipality's financial self-sufficiency level);

$K_{2}$ number of features of the socio-economic situation;

$\beta$ vector of parameters;

$\varepsilon_{i}$ random term for ith municipality, which is assumed to have a standard logistic distribution.

The modeling procedure is performed for cumulative logits, that is, log-ratios of probability that municipality $i$ belongs to a category no higher than $j\left(p_{i j}\right)$ and probability of the opposite event (1$p_{i j}$ ). In the case of $J$ categories (established based on the value of the synthetic feature), $J-1$ logit models are formulated (Hilbe, 2009):

$$
\operatorname{logit}\left(p_{i j}\right)=\ln \frac{\operatorname{Pr}\left(y_{i} \leq j\right)}{\operatorname{Pr}\left(y_{i}>j\right)}=\ln \frac{p_{i j}}{1-p_{i j}}=\beta_{0 j}+\beta_{1} x_{1 i}+\beta_{2} x_{2 i}+\ldots+\beta_{K_{2}} x_{K_{2} i}
$$

for $j=1,2, \ldots, J-1$, where: $p_{1}+p_{2}+\ldots+p_{J}=1, \beta_{0 j}$ denotes category-specific threshold and ${ }_{1} \cdots K_{2}$ are the regression coefficients.

It is worth to be noted that the proposed model is based on the assumption of proportional odds, which implies that there is only one set of regression coefficients for each explanatory variable, as the ratio between all category pairs within the same group of comparisons is assumed to be proportional. Otherwise, a generalized ordered logit model could be estimated, as many regression coefficients for each explanatory variable as the number of financial condition levels minus 1. The assumption of proportional odds can be verified by means of the Brant test (Brant, 1990; Long, Freese, 2006).

\section{Assessing the financial self-sufficiency of municipalities in the Wielkopolskie voivodeship}

In the first phase of the study, addressing the assessment of financial self-sufficiency of municipalities in the Wielkopolskie voivodeship, the following 8 features of the LGUs considered were initially selected based on substantive grounds: share of own incomes in total incomes (\%) $\left(x_{1}\right)$, share of own incomes and total subsidies in total incomes (\%) $\left(x_{2}\right)$, level of own incomes (in PLN per capita) $\left(x_{3}\right)$, fiscal wealth indicator (in PLN per capita) $\left(x_{4}\right)$, fiscal autonomy indicator (share of tax incomes in current incomes) $(\%)\left(x_{5}\right)$, financial state intervention indicator (state budget contribution to total incomes) ( $\%)\left(x_{6}\right)$, self-financing ratio (share of operating surplus and property incomes in property expenditure, $\%)\left(x_{7}\right)$, and share of investment expenditure in total expenditure $(\%)\left(x_{8}\right)$ (Kozera et al., 2016). The set of features established based on substantive grounds was subject to further statistical verification to determine their potential information (correlation with other features) and discriminatory capacity (i.e., variability across the objects considered). Afterwards, based on the statistical analysis, 6 features were selected, describing the financial self-sufficiency level of local government units, that is, $x_{1}, x_{3}, x_{4}, x_{5}, x_{6}$ and $x_{8}$. Then, five of the features were assumed to have a stimulating effect $\left(x_{1}, x_{3}, x_{4}, x_{5}, x_{8}\right)$ and only one feature $\left(x_{6}\right)$ to have a destimulating effect on the level of financial self-sufficiency of LGUs. The feature with a destimulating effect was converted into an opposite feature with the use of a negative 
coefficient. The set of variables retained for the study includes features that demonstrate a strong asymmetry and outlying observations. Therefore, it seems justified to employ the positional TOPSIS method based on the Weber's median and on median absolute deviations from the positive ideal solution and negative ideal solution. For this aim, the values of selected features were normalized using the Weber's median standardization (the calculations were performed with robustX in $R$ ) (Stahel, Maechler 2012). The standardized values of features allowed us to calculate the distance of each municipality considered from the pattern and anti-pattern with the use of the median absolute deviation. Subsequently, the values of the synthetic indicator of LGU financial selfsufficiency levels were calculated using the TOPSIS method, becoming the basis for identifying five types of municipal financial self-sufficiency levels in the Wielkpolskie voivodeship. In the typological classes identified, intra-class values of financial indicators used to establish the synthetic indicator were calculated (Table 1).

Intra-class mean a) values of indicators of financial self-sufficiency levels of Table 1 municipalities of Wielkopolskie voivodeship, Poland, in 2013

\begin{tabular}{|c|c|c|c|c|c|c|}
\hline \multirow{2}{*}{$\begin{array}{l}\text { Specification } \\
\text { Typological class }\end{array}$} & \multicolumn{5}{|c|}{$\begin{array}{c}\text { Typological class - The level of financial self- } \\
\text { sufficiency }\end{array}$} & \multirow{2}{*}{$\begin{array}{l}\text { Wielkopolskie } \\
\text { voivodeship }\end{array}$} \\
\hline & $\begin{array}{c}\text { I } \\
\text { very } \\
\text { high } \\
\end{array}$ & $\begin{array}{l}\text { II } \\
\text { high }\end{array}$ & $\begin{array}{c}\text { III } \\
\text { average }\end{array}$ & $\begin{array}{l}\text { IV } \\
\text { low }\end{array}$ & $\begin{array}{l}\text { v } \\
\text { very } \\
\text { low }\end{array}$ & \\
\hline Number of municipalities b) & 7 & 4 & 46 & 110 & 55 & 222 \\
\hline $\begin{array}{l}\text { Percentage of municipalities } \\
(\%)\end{array}$ & 3.2 & 1.8 & 20.7 & 49.5 & 24.8 & 100 \\
\hline $\begin{array}{l}\text { Share of own incomes in total } \\
\text { incomes }(\%)\end{array}$ & 74.0 & 62.0 & 51.1 & 40.5 & 29.7 & 41.8 \\
\hline $\begin{array}{l}\text { Level of own incomes (in } \\
\text { PLN per capita) }\end{array}$ & 3681.8 & 2288.9 & 1717.4 & 1259.7 & 878.8 & 1260.6 \\
\hline $\begin{array}{l}\text { Fiscal wealth indicator (in } \\
\text { PLN per capita) }\end{array}$ & 1996.3 & 775.6 & 683.0 & 508.3 & 379.0 & 515.6 \\
\hline $\begin{array}{l}\text { Fiscal autonomy indicator } \\
(\%)\end{array}$ & 39.7 & 26.2 & 24.2 & 18.6 & 13.5 & 18.6 \\
\hline $\begin{array}{l}\text { Financial state intervention } \\
\text { indicator }(\%)\end{array}$ & 25.5 & 37.4 & 41.5 & 54.9 & 67.3 & 54.8 \\
\hline $\begin{array}{l}\text { Share of investment } \\
\text { expenditure in total } \\
\text { expenditure }(\%)\end{array}$ & 18.4 & 26.3 & 16.4 & 12.0 & 11.7 & 12.6 \\
\hline
\end{tabular}

As shown by the empirical study, typological classes with very high and high levels of financial self-sufficiency collected the $3.2 \%$ and $1.8 \%$, respectively, of the total number of Wielkopolskie voivodeship municipalities. Class 1 , demonstrating a very high level of municipal financial selfsufficiency, was composed of seven municipalities (Suchy Las, Przykona, Kleczew, Tarnowo Podgorne, Powidz, Komorniki and Kornik). Four of them are located in the immediate vicinity of the city of Poznan, the largest city of the Wielkopolskie voivodeship. The proximity of the metropolitan centreprovides the LGUs with financial benefits. The suburbanization process, which has been observed for several years, results in a dynamic development of the residential function of rural areas, especially in municipalities located in the first ring around large urban centres. The consequence is the development of infrastructure (residential housing, transport lines, commercial and service facilities in suburban areas) and the creation of bedroom communities for the commuting population. In the Przykona municipality, the high level of financial self-sufficiency 
results from the operation of a local lignite mine (high mining fees contributing to the municipal budget). In turn, as regards the Powidz municipality, that situation primarily results from the operation of a military air base in that area. The first type of LGUs were characterized by the highest share of own incomes in total incomes (74\%), the highest level of own incomes per capita (PLN 3,681.8), the highest level of fiscal wealth (PLN 1,996.3), and a minor financial state intervention $(25.5 \%)$. Average levels of financial self-sufficiency were reported by 46 municipalities grouped in the third typological class $(20.7 \%$ of all municipalities of the Wielkopolskie voivodeship). In these municipalities, own incomes per capita were less than half the amount recorded for the first type of municipalities (PLN 1,717.4 per capita). Note also that own incomes represented one half of total incomes (51.1\%). In turn, the fourth and fifth typological class, demonstrating low and very low levels of financial self-sufficiency, respectively, were composed of 110 and 55 municipalities of the Wielkopolskie voivodeship, respectively. Around a quarter of municipality surveyed (nearly $25 \%$ of the total population) reported a distinctively low level of financial self-sufficiency. These LGUs were characterized by the lowest level of own incomes per capita (barely PLN 878.8) and, at the same time, the lowest share of own incomes in total incomes (less than $30 \%$ ). In these municipalities, the low levels of own incomes per capita and low shares of own incomes in their budgets resulted in the lowest share of investment expenditure in the total expenditure. This contributed to a slower socio-economic development of the regions concerned. These were mainly agricultural municipalities located away from large urban centres(Table 1).

\section{Identification of socio-economic determinants of financial self-sufficiency levels of municipalities in the Wielkopolskie voivodeship}

Together with the system of socio-economic development indicators, the identified classes were the basis for modeling the financial self-sufficiency level of municipalities in the Wielkopolskie voivodeship. From a predefined set of 18 socio-economic indicators, the following exogenous variables were retained: share of economic operators with 10 to 49 employees (\%), share of economic operators with 50 or more employees (\%), share of rural population in the total population ( $\%)$, official unemployment rate $(\%)$, number of hotel beds per 1,000 population. Table 2 shows the results of the estimation of parameters for the ordered logit model of financial self-sufficiency of municipalities in the Wielkopolskie voivodeship (calculations performed with GRETL $^{1}$ (Gnu Regression, Econometric Time-series Library) (Adkins 2014, Cottrell, Lucchetti 2018). The estimated model fits well the empirical data (McFadden's $R^{2}=40.2 \%$, McKelvey and Zavoina's $R^{2}=66.8 \%$, Count $R^{2}=78.2 \%$ ) and demonstrates high statistical significance (at $p<0.05$ ) of most regression coefficients.

As shown by the empirical study, an increase in the value of explaining variables (ceteris paribus) such as official unemployment rate (\%) and share of rural population (\%) resulted in reducing the odds of the municipalities for moving to a higher level of financial self-sufficiency (0.162 and -0.012 , respectively) from one of the lower levels. This is because the personal income tax (which is one of the main sources of LGU incomes) and other taxes contribute much less to the budgets of municipalities with a high share of population working in agriculture and a high official unemployment rate. In Poland, the agricultural tax is the main tax burden imposed on farms, and contributes to the budgets of municipalities where the taxable land is located. Just as in many EU

${ }^{1}$ GRETL is available on the website: http://www.gretl.eu/ 
countries, Polish fiscal solutions include specific provisions for a more favoruable treatment of the agriculture sector. This is reflected in many ways, including the exemption of agricultural incomes from income tax. In the case of agriculture, the favoruable treatment extends beyond income tax. For instance, the property tax also plays a minor role in the agricultural taxation system. This is because an exemption is applicable to agricultural buildings and parts thereof which are located on farmland and are used solely for farming. The agriculture is also exempt from vehicle taxes, inheritance taxes and gift taxes. Note also the very limited fiscal efficiency of the agricultural tax in Poland because the tax rates are not linked to actual outputs and economic performance of farms. As a consequence, typically agricultural municipalities demonstrate lower levels of own income potential and financial autonomy (Kozera, 2017).

Results of the estimation of parameters for the ordered logit model

Table 2 of financial autonomy of municipalities in the Wielkopolskie voivodeship, Poland

\begin{tabular}{|l|c|c|c|c|c|}
\hline \multicolumn{1}{|c|}{ Explanatory (independent) variables } & Coefficient & $\begin{array}{c}\text { Std. } \\
\text { Error }\end{array}$ & $\begin{array}{c}\text { Odds } \\
\text { ratio }\end{array}$ & $\begin{array}{c}\boldsymbol{p} \text { - } \\
\text { values }\end{array}$ & Symbola) $^{\text {Sym }}$ \\
\hline Official unemployment rate ( \%) & -0.162732 & 0.059588 & 0.849819 & 0.0063 & $* * *$ \\
\hline $\begin{array}{l}\text { Share of rural population in the total } \\
\text { population ( \%) }\end{array}$ & -0.012527 & 0.004725 & 0.987551 & 0.0080 & $* * *$ \\
\hline $\begin{array}{l}\text { Share of economic operators with 50 or } \\
\text { more employees ( \%) }\end{array}$ & 0.059236 & 0.028709 & 1.061026 & 0.0391 & $* *$ \\
\hline $\begin{array}{l}\text { Share of economic operators with 10 to 49 } \\
\text { employees (\%) }\end{array}$ & 0.014865 & 0.008572 & 1.014976 & 0.0829 & $*$ \\
\hline $\begin{array}{l}\text { Number of hotel beds per 1,000 } \\
\text { population }\end{array}$ & 0.006715 & 0.002519 & 1.006737 & 0.0077 & $* * *$ \\
\hline
\end{tabular}

a) If $p$-value $<0.001$ it is flagged with three stars $(* * *), 0.001<p$-value $<0.05-$ two stars $(* *), 0.05<p$-value $<0.1-0$ one star.

Source: authors' study based on the Local Data Bank of the Central Statistical Office in Poland

Conversely, other variables retained in the model had a stimulating effect on the odds for increasing the financial self-sufficiency of administrative units. As shown by the empirical study, a municipality would have the greatest odds ratios for improving its financial condition in the case of an increase in: the share of economic operators with 50 or more employees (6.1\%); the share of economic operators with 10 to 49 employees (1.5\%); and the number of hotel beds per 1,000 population. The above features have a direct impact on the level of own incomes because the growing economic potential results in an increased contribution of the most important (most efficient) sources of own incomes, i.e. property tax, personal income tax and corporate income tax.

\section{Conclusions, proposals, recommendations}

The proposed approach to a multidimensional analysis of financial self-sufficiency levels of local government units was implemented with the use of taxonomic methods and the ordered logit model. Combined with taxonomic methods, the ordered logit model enables a more in-depth analysis of the reasons for differences in the financial condition of administrative units.

1) The analysis of the financial situation of local government units (e.g. the assessment of financial self-sufficiency levels) deals with complex aspects that cannot be directly measured. Therefore, the taxonomic methods (i.e. TOPSIS and the Weber's positional median) were used to synthetically assess and identify the types of financial self-sufficiency levels in Wielkopolskie voivodeship municipalities in Poland. This is a suitable approach to determine the synthetic development indicator in a case where the set of features of units under consideration includes 
outliers or strongly asymmetrical values. This is exactly the case in the analysis of financial situation of local government units.

2) The identified classes of financial self-sufficiency levels of the municipalities became the starting point for the subsequent econometric analysis. They represented ordered categories of the explained variable in a logit model combined with a system of socio-economic development indicators. The ordered logit model used in this study proved to be a useful tool for the identification of determinants of the administrative units' financial condition. This model allowed us to specify the significance (strength and direction) of selected socio-economic development factors for the financial self-sufficiency level of municipalities. The retained exogenous variables, extending to selected socio-economic factors, had a statistically significant impact on financial self-sufficiency levels of administrative units. As confirmed by the study, the following had a stimulating impact on the improvement of financial autonomy levels of administrative units under consideration: the share of economic operators with 50 or more employees; the share of economic operators with 10 to 49 employees; and the number of hotel beds per 1,000 population. In turn, such variables as the official unemployment rate and the share of rural population proved to have a destimulating effect.

3) The proposed approach to assess the financial self-sufficency levels of municipalities in the Wielkopolskie voivodeship, Poland, is a universal technique that may be used for other administrative units. The proposed research approach may also be the basis for the establishment of development documents, e.g. development strategies.

\section{Bibliography}

1. Adkins, L. C. (2014): Using gretl for Principles of Econometrics, 4th Edition Version 1.041. (http://www.learneconometrics.com/gretl/using_gretl_for_POE4.pdf).

2. Bank Danych Lokalnych (Local Data Bank), Central Statistical Office, Poland (www.stat.gov.pl).

3. Borooah, V. K. (2001). Logit and Probit: Ordered and Multinomial Models. Series: Quantitative Applications in the Social Sciences, Sage University Paper 07-138. Thousand Oaks, CA: Sage.

4. Brant, R. (1990). Assessing proportionality in the proportional odds model for ordinal logistic regression. Biometrics, Volume 46, no. 4, pp. 1171-1178.

5. Cameron, A.C., Trivedi, P.K. (2005): Microeconometrics. Methods and Applications. Cambridge University Press, Nowy Jork.

6. Cottrell, A., Lucchetti, R. (2018): Gretl User's Guid. Gnu Regression, Econometric and Time-series Library. Department of Economics and Wake Forest University and Dipartimento di Economia Universit 'a Politecnica delle Marche (http://ricardo.ecn.wfu.edu/pub//gretl/manual/PDF/gretl-guide.pdf).

7. Cramer, J.S. (2011). Logit Models from Economics and Other Fields. Cambridge University Press, Cambridge.

8. Hellwig, Z. (1972). Procedure of Evaluating High-Level Manpower Data and Typology of Countries by Means of the Taxonomic Method. In. Gostkowski Z. (ed.): Towards a System of Human Resources Indicators for Less Developed Countries: Papers Prepared for a UNESCO Research Project, Ossolineum. Polish Academy of Sciences Press, Wrocław, p.p. 115-134.

9. Hilbe, J.M. (2009). Logistic Regression Models. Chapman \& Hall/CRC Press, Boca Raton.

10. Hwang, C.L., Yoon, K. (1981). Multiple Attribute Decision Making: Methods and Applications. Springer, Berlin.

11. Kozera, A. (2017). Podatek rolny jako zrodlo dochodow wlasnych gmin wiejskich w Polsce (Agricultural Tax as a Source of Own Income of Rural Communes in Poland). Roczniki Naukowe Ekonomii i Rozwoju Obszarow Wiejskich, Volume 104, No. 2, pp. 76-86.

12. Kozera, A., Głowicka-Wołoszyn, R., Wysocki, F. (2016). Samodzielnosc finansowa gmin wiejskich w woj. wielkopolskim (Financial Self-Sufficiency of Rural Communes in Greater Poland Province). Wiadomosci Statystyczne (Statistical News), Np. 2, pp. 73-86.

13. Lira, J., Wagner, W., Wysocki, F. (2002). Mediana w zagadnieniach porzadkowania obiektow wielocechowych. In: Paradysz J. (ed.): Statystyka regionalna w słuzbie samorządu terytorialnego i biznesu. Akademia Ekonomiczna w Poznaniu, Poznan, pp. 87-99.

14. Long, J.S., Freese, J. (2006). Regression Models for Categorical Dependent Variables Using Stata (second edition). Stata Press Publication, College Station, Texas. 
15. Łuczak, A., Wysocki, F. (2013). Zastosowanie mediany przestrzennej Webera i metody TOPSIS w ujeciu pozycyjnym do konstrukcji syntetycznego miernika poziomu zycia (The Application of Spatial Median of Weber and the Method TOPSIS in Positional Formulation for the Construction of Synthetic Measure of Standard of Living). Prace Naukowe Uniwersytetu Ekonomicznego we Wrocławiu, No. 278. Taksonomia 20, pp. 63-73.

16. Mlodak, A. (2006). Analiza taksonomiczna w statystyce regionalnej (Taxonomic Analysis in Regional Statistics). Difin, Warszawa.

17. Pratchett, L. (2004). Local Autonomy, Local Democracy and the 'New Localism'. Political Studies, Volume 52.

18. Stahel W., Maechler M. (2012): Package 'robustX'. eXperimental eXtraneous eXtraordinary ... Functionality for Robust Statistics. Version 1.1-3. (cran.r-project.org/web/packages/robustX).

19. Standar, A., Kozera, A. (2017). Uwarunkowania spoleczno-ekonomiczne ksztaltowania sie poziomu wlasnego potencjalu dochodowego gmin wiejskich wojewodztwa wielkopolskiego (Socio-Economic Determinants of the Level of Own Potential Income of Rural Communes in Wielkopolska Province). Finanse, Rynki Finansowe, Ubezpieczenia, Volume 1 (85), pp. 695-707.

20. Surówka, K. (2013). Samodzielnosc finansowa samorzadu terytorialnego w Polsce (Financial Self-Sufficiency of Local Government Units in Poland). Polskie Wydawnictwo Ekonomiczne, Warszawa.

21. Wysocki, F. (2010). Metody taksonomiczne w rozpoznawaniu typow ekonomicznych rolnictwa i obszarow wiejskich (Taxonomic Methods in Recognizing Economic Types of Agriculture and Rural Areas). Wydawnictwo Uniwersytetu Przyrodniczego w Poznaniu, Poznan. 